\title{
Geographical and Legal Problems of Delimitation of the Arctic Territories in the Krasnoyarsk Territory (Krai)
}

\author{
Leonid A. Bezrukov* \\ V.B. Sochava Institute of Geography $S B R A S$, \\ 1 Ulan-Batorskaya, Irkutsk, 664033, Russia,
}

Received 09.06.2016, received in revised form 12.08.2016, accepted 30.08.2016

The present study deals with the geographical and legal problems of delimitation of the North and Arctic territories in the Krasnoyarsk Territory (Krai). With respect to the legislative delimitation of the North as a separate entity, it provides characteristics the three main latitude zones of the Krasnoyarsk Territory (Krai): the South (the Southern Latitude Belt), the Near North, and the Far (Extreme) North, along with the respective principles of territorial policy. The emphasis is placed on the insufficient substantiation of the "Arctic zone" delimitation on land, especially on the existing contradictions between its boundaries and the boundaries of the Extreme North zone. The article also explores the problem of political and legal regulation as regards the demarcation of the water area of the Arctic Ocean, which arose after the entry of the 1982 UN Convention on the Law of the Sea (UNCLOS) into force, as its principal provisions were fundamentally different from the historically established division of the Arctic into five polar sectors belonging to Russia, Canada, the USA, Denmark and Norway. Some issues related to the influence of the differences in the Arctic maritime spaces' legal status on the peculiarities of the development of their natural resources are also covered.

Keywords: Arctic, North, delimitation, maritime space, legal status.

This paper was prepared with the financial support from the Russian Humanitarian Science Foundation (RHSF) and the Krasnoyarsk Territory (Krai) Science Foundation (project no. 16-12-24007 "Development of long-term scenarios and organizational-economic mechanisms of development of the Arctic zone of the Krasnoyarsk Territory (Krai), and assessment of their influence on the socioeconomic state and dynamics of the Krasnoyarsk Territory (Krai)").

DOI: 10.17516/1997-1370-2016-9-10-2351-2364.

Research area: economic, social, political and recreational geography.

\section{Introduction}

Everyone knows the symbolic prophesy of a great Russian encyclopaedist and scientist M.V. Lomonosov, that the power of Russia would grow with Siberia and the Arctic Ocean. It has proven true concerning Siberia and the North; now it is the time for the North Arctic Ocean and the Arctic as a whole to follow.

In the last two decades more attention has been drawn to the problems of the North and the Arctic due to the growth of their relevance for the development of Russia and the whole world. It is

(C) Siberian Federal University. All rights reserved

* Corresponding author E-mail address: bezrukov@irigs.irk.ru 
the place where an enormous amount of natural resources is concentrated; the deposits have been developed at full throttle on the continent and in the near future exploration of the Arctic seas' shelf is planned. The large-scale extraction of raw materials in the Northern areas covers the major part of export and income part of Russia's federal budget. An exceptional role in its transport system is played by the Northeast Passage (NEP) with its transit potential drawing more and more interest of the world community. With the current activation of the Western pressure on Russia, military and strategical significance of the North and the Arctic are obviously growing; it manifests itself in the territorial depth of defence, powerful nuclear fleet placement, free outlet to the World ocean (including open water areas of the Atlantic and the Pacific), presence of short trajectories for hitting important targets. The Russian North is also the greatest array of natural ecosystems in the world, serving as a biosphere reserve of the Earth.

At the same time, despite the obvious growth of research and publications on the relevant issues of the North and Arctic, delimitation issues remain understudied. Generally, delimitation is understood as outlining (identification) and mapping of the studied taxons (Alaev, 1983). There are multiple works dedicated to the delimitation issues of the Russian North and the Arctic, but no consensus has been reached; consequently, using the same terms, different authors mean a significantly different set of territories, while the boundaries between the North, Extreme North, Polar zones, Arctic, and Subarctic remain indefinite. To a great extent it is explained by the vagueness of the North and the Arctic terms themselves, uncertainty in the delimitation purpose and criteria, absence of a substantiated common quantitative approach to delimitation, contradictions between certain provisions of Russian and international legislations etc.
With regard to the North, the subject matter is its so-called "administrative" border which defines the term of the North as per Russian legislation. Delimitation of the North and its internal division are essential for solving the acute problem of finding a territorially differentiated approach to provision of state support to the population, compensation of the extra expenses on accommodation and economic activities they suffer under the severe natural and climatic conditions. Soothing the contrast between the Northern and more comfortable Southern regions, achievement of a certain macro-territorial fairness is an extremely relevant issue of Russia's regional policy of a great socioeconomic and political significance.

Unlike delimitation of the North as Russia's domestic issue, delimitation of the Arctic is greatly complicated by the external, international factors; therefore, often the subject matter of the issue is the state border of the country. In the meanwhile, the international legal status of the Arctic is going through another stage of formation, which brings ambiguousness to the identification of belonging and status of wide maritime areas, courses of boundaries, and outlining the influence zones of different states. At the same time, delimitation of the North Arctic Ocean area remains politically and legally unregulated, there is a growing tendency of Arctic internationalization by creating so-called "world heritage areas" and penetration of nonArctic states into it. The issue of drawing the South border of the Arctic on the continent and the relation of such border to the internal division of the North also remains disputable.

Let us study the following geographic and legal issues and delimitation issues of the North and the Arctic based on the situation of the Krasnoyarsk Territory (Krai):

- latitude zoning, outlining the North and its "official" areas; 
- outlining of the Arctic zone on land and its relation to the Extreme North zone;

- division of the North Arctic Ocean between the Arctic nations, legal status of Arctic maritime spaces and its influence on the peculiarities of natural resources development.

\section{Latitude zoning of the Krasnoyarsk Territory (Krai)}

Despite the great research and legislative basis in the field of the delimitation of the North, developed back in the 1990-s, the basic Federal Law "On the regional delineation of the North of Russia" has not been passed yet. In fact, Soviet regulative documents, primarily, "The list of areas of the Extreme North and equated localities" (Perechen' rayonov..., 2002), approved by the Decree of the USSR Cabinet in 1967 (with multiple subsequent changes and additions), are still in action. The mentioned list was based on the scheme drawn up by S.V. Slavin back in the 1930-s (Slavin, 1961), which is obviously obsolete in many ways.

Nevertheless, the legislation clearly defines the terms "areas of the Extreme North" and "localities equated to the Extreme North". In scientific literature, these terms correspond to the two Northern latitude zones: "the Far North" and "the Near North" correspondingly (for example, Slavin, 1961; Ekonomika Sibiri..., 1985).

On the basis of such legislative delineation of the North and in accordance with the differentiation of natural, climatic and economic conditions, the Krasnoyarsk Territory (Krai), just like Russia as a whole, is fair to be seen as three main latitude areas: South (Southern latitude belt), Near North, Far (Extreme) North (see Fig. 1). The ways of development and functions of the said zones, as well as principles of their territorial policy, are different in many ways.

The Southern latitude belt covers the most developed and populated of the Krasnoyarsk
Territory (Krai), its axis being the TransSiberian Railway (the Trans-Siberian). With its comparatively comfortable natural and climatic conditions, this area is quite suitable for normal life. The Southern latitude zone covers only $10.3 \%$ of the Krai territory, but concentrates $84.8 \%$ of its population (see Table 1). Located in the South and being the centre of the region from economic point of view, it hosts the main economic domains and the major part of the population. It has a rich railway network and year-round motorways, as well as some big cities including the administrative centre of the Krai, Krasnoyarsk, with the population of one million people.

The habitable and well-developed South of the Krasnoyarsk Territory (Krai), being the South of entire Siberia, located in the middle part of Russia, is its strategic territorial reserve and may become a powerful launching ground for new industrialization, thanks to the large developing processing industries, intensive agriculture, advanced transport and energy supply systems. The major task is to form a complete industrial structure by improving raw material processing and final stages of production (the "upper stories") both on the existing industrial base and the new base of raw materials expected to arrive from the Northern areas. The basic principles of this zone's territorial policy include measures for settlement and involvement of population, which requires, first of all, provision of life standards higher than the country's average by improving the system of coefficients and wage increments, and bringing the social infrastructure and comfort of living closer to the best domestic and international standards.

The Near North zone of the Krasnoyarsk Territory (Krai) includes taiga areas in the North of the Southern latitude belt, remarkable for severe natural and climatic conditions, though located relatively close to the main 


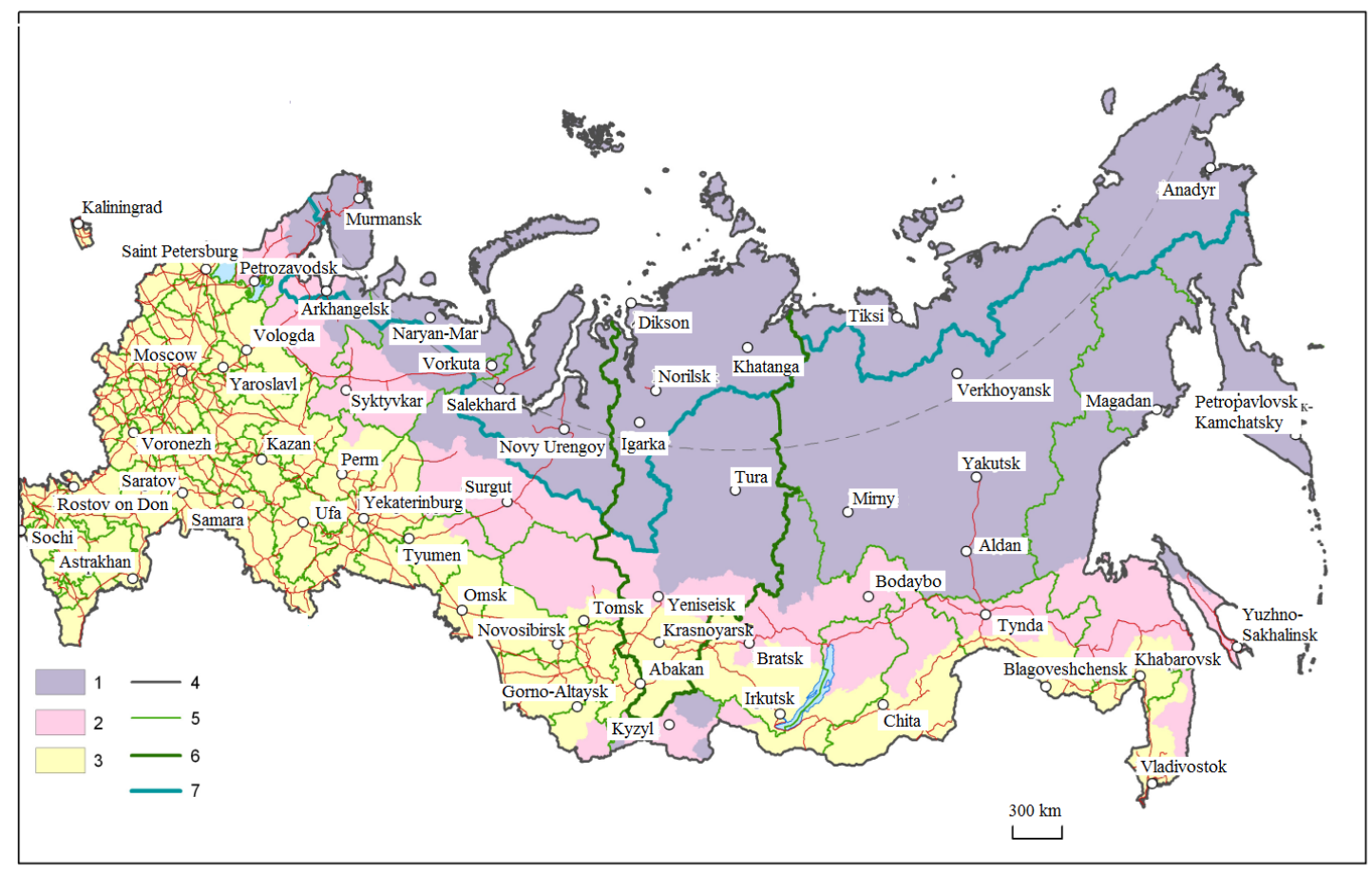

Fig. 1. Latitude zones of Russia as per legislation, as of 01.01.2014: 1 - Extreme North (Far North) areas; 2 localities equated to the Extreme North (Near North); 3 - Southern latitude belt (the South). Borders: 4 - state border of the RF; 5 - border of the constituent entities of the RF; 6 - border of the Krasnoyarsk Territory (Krai); 7 - border of the land territories of the Arctic zone of the Russian Federation

Table 1. Latitude zones of the Krasnoyarsk Territory (Krai)

\begin{tabular}{|c|c|c|c|c|}
\hline \multirow{2}{*}{ Latitude zones } & \multicolumn{2}{|c|}{ Area } & Population (according to the Census-2010) \\
\cline { 2 - 5 } & Thousand sq.km. & $\%$ & Thousand people & $\%$ \\
\hline South & 244.4 & 10.3 & 2400.1 & 84.8 \\
Near North & 213.6 & 9.0 & 171.4 & 9.1 \\
Far North & 1908.8 & 80.7 & 256.7 & 8.1 \\
including & 1098.4 & & & 100 \\
Arctic zone & 2366.8 & 100 & 229.3 & \\
\hline Total & & & 2828.2 & \\
\hline
\end{tabular}

railway grid. The Near North zone covers $9.0 \%$ of the Krai territory with the $6.1 \%$ of its population (Yeniseisk, Motygino, Boguchany, Kezhemsk Districts, the cities of Yeniseisk and Lesosibirsk). This zone is characterized with a transport and economic connection to the Southern latitude belt despite the absence of big cities.
The Near North zone needs selective development of resources, and, most of all, preliminary improvement of transport network, determination of a more rational pattern of settlement and building economic activity on the basis of permanent and rotational housing. Thus, the actively forming Nizhneangarsk facility is developing through permanent 
housing construction. Another important territorial policy principle of the zone is the need for the North legislation arrangement, including bringing the current regional system of coefficients, wage increment and compensation in compliance with the Northern level of expense, providing such increments regardless of the occupation of people in the public or private business sector.

The Far (Extreme) North of the Krasnoyarsk Territory (Krai) includes wide, sparsely populated spaces of the Arctic deserts, tundra, Northern and middle taiga, located further to the North, including the islands of the North Arctic Ocean and its seas. The Far Northern latitude zone occupies the major part of the whole territory of the Krai, $80.7 \%$, with a relatively little share of its population, 9.1\% (Taymyr Dolgano-Nenets, Evenki, Turukhansk, SeveroYeniseisk Districts and the city of Norilsk). For this zone, transport and economic connection to the Southern latitude belt is less typical, while economic connection through the Northeast passage and the maritime ports of the other regions, first of all, with Murmansk, is just as important. As a rule, the Far North districts are cut off from the year-round communication with the continent; those are periphery territories with predominantly extensive farming, sparse settlement grid and huge unpopulated areas. Nevertheless, there is such a big city as Norilsk, which is one of the top 10-15 largest industrial centres of Russia.

The Far North spatial development strategy should be based on the main peculiarities of this huge territory, which dramatically raise the price of its development, reduce the efficiency of farming and investment attractiveness. Among the general peculiarities there are the following: severe and even extreme the natural and climatic conditions; uncomfortable and adverse conditions of living, low and extremely low degree of economic development and density of population, hard access due to the absence of year-round transportation and opportunities for maintaining connection to the mainland. It dictates strict localization of production in the few points of the best resources concentration or the best economic and geographic position, exclusively selective (targeted) development oriented on the most efficient projects only.

Another peculiarity of the Far North is that fact that the major part of its territory, over $86 \%$, is occupied by municipal entities formed on the ethnic principle (Taymyr and Evenki Districts). For this reason, natural resources development should be done with full respect to the interests of the indigenous peoples, providing advantageous conditions for traditional nature use and functioning of the traditional settlement patterns. Besides the North legislation arrangement, it requires such principles of territorial policy as maximal use of the existing settlements' potential in new development projects, priority of rotational and expedition exploration methods and preference of intra-regional rotation to interregional one etc.

Considering the significance of the "latitude zoning" and "the North" terms, a comprehensive and fundamental substantiation and enactment of the basic Federal Law "On regional delineation of the North of Russia" is required. It should sufficiently stipulate the issues of guarantees, compensations and allowances provided to the North population along with the justification of territorial differentiation of the regional (territorial) policy in the North latitude zone context. This way, the problem of delimitation of the North and latitude zone delineation turns out to be an acute political, social and economic problem, as long as it is put into practice from being an exclusively theoretical and methodological problem of geography and adjacent sciences. 


\section{Problems of the Arctic zone delineation on land and its relation \\ to the Extreme North zone}

Compared to that of "the North", the term of "the Arctic" is more definite. The Arctic is usually understood as the Northern polar part of the globe including continental margins of Eurasia and North America, as well as almost the entire North Arctic Ocean with all of its islands, and the adjacent parts of the Atlantic and Pacific Oceans. At the same time, the unambiguous delimitation of the Arctic remains an open issue. According to the geodesic criterion, it covers the land and maritime territories to the North from the Arctic Circle, being a synonym for the Polar zone. According to the climatic criterion, the Southern border of the Arctic may be the average July isotherm of $+10^{\circ} \mathrm{C}$, drawing the line between tundra and forest tundra. According to the biogeographic forestation criterion, the Southern border of the Arctic would be drawn even further South, on the borderline between forest tundra and taiga.

The said criteria bear physical and geographic character, identifying the Arctic as, first of all, a natural region and secondly, as a specific, the least comfortable part of the North with extreme natural conditions. Still, delimitating the Russian part of the Arctic, one should be guided rather with the state administration priorities, necessity to differentiate regional policy and provide sovereign rights of Russia in the high latitudes rather than with physical or geographic criteria. Such "legislative" delimitation on land has actually been carried out by the Decree of the President of the Russian Federation "On land territories of the Arctic Zone of the Russian Federation" (Ukaz No. 296, 2014).

The Arctic Zone includes: a) entire constituent entities of the Russian Federation (Murmansk Oblast, Nenets, Yamalo-Nenets, Chukotka Autonomous Okrugs); b) municipal districts and cities of Arkhangelsk Oblast, the Krasnoyarsk Territory (Krai) (Taymyr DolganoNenets District) and Sakha (Yakutia), adjacent to the seas of the North Arctic Ocean; c) some districts and cities of Komi Republic (Vorkuta) and the Krasnoyarsk Territory (Krai) (Turukhansk District and Norilsk), remote from the sea coast (see Fig. 1). According to the author's calculations, the area of the zone constitutes 3.5 million sq.km. (20.5\% of the entire territory of Russia) with the permanent population of 2.4 million people (less than $1.7 \%$ of the country's population according to Census-2010).

The central position in the Arctic Zone of Russia is occupied by the Arctic territories of the Krasnoyarsk Territory (Krai), the area of which is approximately 1.1 million sq.km., or $31.4 \%$ of the entire zone area. The share of the Arctic Zone in the total area of the Krai is great, constituting $46.4 \%$ (see Table 1).

Analysis of the territorial composition and configuration of the Southern border of the Arctic Zone inevitably raises a number of questions. As we know, the mentioned Decree (Ukaz No. 296, 2014) was passed to develop the basic document "Basic state policy of the Russian Federation in the Arctic for the period until the year 2020 and further prospective" (Osnovy..., 2009). The document lists the following characteristics of the Arctic Zone of Russia: extreme natural and climatic conditions, cellular development, low population density, remoteness from the main industrial centres and high dependence on supplies from other regions, low ecosystem sustainability. Based on the first characteristic, the zone is expected to be the least comfortable high latitude part of the Extreme (Far) North. However, in Arkhangelsk Oblast the border of Arctic is drawn, for some reason, farther South than the border of the Extreme North, while the Southern Border of Yamalo-Nenets Autonomous Okrug partially coincides with the both said borders. 
Classification of the entire Turukhansk District as a part of the Arctic zone also raises some questions, as a result, the Arctic status was also given to some areas of the Krasnoyarsk Territory up to the mouth of the Podkamennaya Tunguska and even farther. It is hard to agree with including Vorkuta, Komi Republic, into the said zone, as well as some parts of YamaloNenets Autonomous Okrug (Krasnoselkupsky etc.), remote from the coast of the North Arctic Ocean.

Agreeing with the opinion (Konovalov, 2014) of the system-forming role of the Northeast Passage for the development of the Arctic Zone of Russia, we may assume that the main criteria of its delimitation is the gravitation of these or those districts to its transportation routes. According to this criterion, it makes real sense to include territories with maritime ports both on the coasts of the North Arctic Ocean seas (Murmansk, Tiksi etc.) and the lower reaches of the Northern rivers (Arkhangelsk, Dudinka, Igarka, Khatanga etc.) into the Arctic. Nevertheless, the reason of including Turukhansk municipal district with the city of Igarka in the North into the same category with the whole of its wide territory is still unclear.

To a great extent the problem is the giant territory of some municipal districts in the North of Siberia and the Far East, counting up to 700-800 thousand sq.km., while, for example, the areas of all regions of the Central Russia "make it" within 20-90 thousand sq.km. Thus, the area of Taymyr Dolgano-Nenets District exceeds 800 thousand sq.km. For this reason, the legislative Southern border of the Arctic Zone should be drawn, to our mind, on a smaller fraction level, i.e. on the borders of smaller municipal entities, such as cities and settlements. Following this principle, it is possible to account for a combination of physical, economic and geographic factors typical for the Arctic. In particular, including
Igarka into the Arctic Zone (within the borders of the same-name town), it appears unreasonable to include the rest of Turukhansk District into it. Similar precedents are found, for instance, in the Republic of Komi, the Khabarovsk and Primorsky Territories (Krais).

Therefore, as a state administration object, the Arctic Zone of Russia is in need for substantiated delimitation, as, according to the underlying documents (Osnovy..., 2009; Ukaz No. 296, 2014), there are important national interests, tasks, targets, strategic priorities and regional policy actualization mechanisms in its regard. It is important to remark that the legislative demarcation of land territories of the Arctic does not assume, at this stage, revision of the existing regional coefficient and wage increment systems. Consequently, the tasks of delimitation of the North and the Arctic hardly coincide with each other.

However, considering the intense attention the Arctic has been attracting in the last decade, introduction of special compensations and allowances to the Arctic Zone population is also possible. This situation creates some obvious legal collisions: thus, the new "Arctic" preferences shall be valid, for instance, in Turukhansk District, but not in Evenki District, despite its location within the same latitude diapason, but with worse transportation and economic conditions. It is absolutely obvious that the Arctic (or, at least, its land territories) is an integral part of the North, and, therefore, delimitation of the North and the Arctic shall correlate to each other to a greater extent.

\section{Legal status of maritime spaces of the Arctic and peculiarities of developing their natural resources}

Despite all the problems of substantiation of the land territories included into the Arctic Zone of Russia, its border on the continent is clearly and 
definitely contoured, which is a domestic issue of the state. Delimitation of maritime spaces of the Artic in the North Arctic Ocean is dramatically different, being complicated by some international factors. Moreover, unlike land borders, the maritime ones are more diverse in functions and are less established. Such peculiarities are typical for maritime spaces of the Arctic, the delimitation of which remain unsettled. The problem is that the historical division of the Arctic into national polar sectors does not coincide in the core with the basic conventions of the 1982 UN Convention on the Law of the Sea, the key international document for delimitation of maritime areas.

Since the 1920-s, five Arctic nations, Denmark (Greenland), Canada, Norway, Russia and the USA, actually divided Arctic into national polar sectors (see Fig. 2). The ground for such national sectors was the Arctic coast of each state, while its side borders were the meridians running through the extreme West and East points of the coast to the North Pole (the top of the sector). Within its sector in the North Arctic Ocean, the states exercised their sovereign rights for the continental coast and the island, but not the water territory, though the states would actually request for permission to get access into the polar sector belonging to other states. It means that practically, each national polar sector was not covered by international law belonging to the state order area. In the modern political maps made in Russia the polar sector of our country

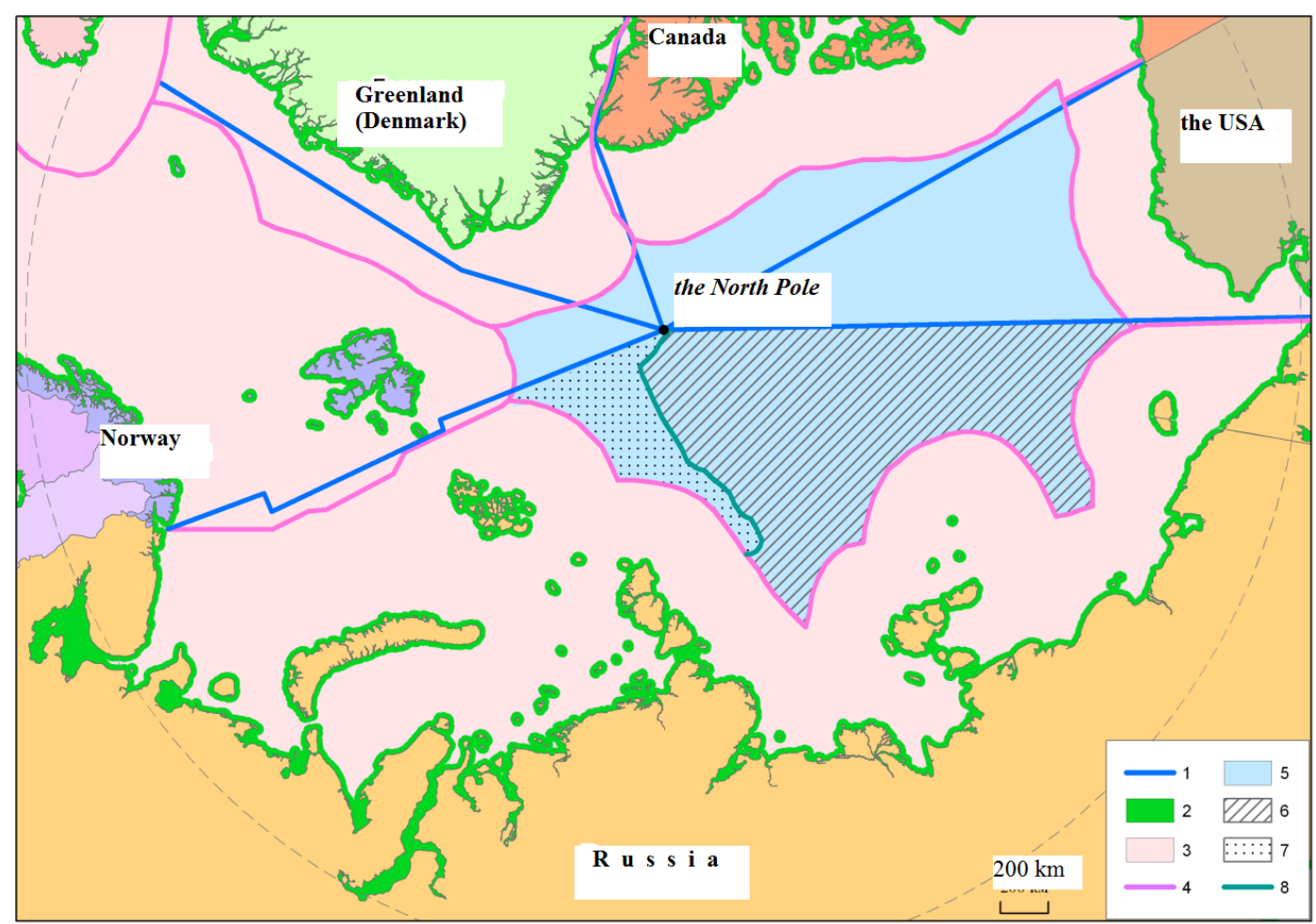

Fig. 2. Delimitation of the North Arctic Ocean based on the sectoral and conventional principles: Delimitation based on the sectoral principle: 1 - borders of the national polar sectors of the Arctic states. Delimitation based on the conventional principle: 2 - inland sea and territorial waters of the states, 3 - exclusive economic zones of the states, 4 - external borders of the exclusive economic zones of the states, 5 - non-distributed maritime areas. The suggested delimitation of the sea territory of the polar sector of Russia beyond the external border of its exclusive economic zone: 6 - part of the continental shelf Russia aspires for; 7 - a part of the polar water territory Russia does not lay claims on, 8 - border between the parts Russia does and does not lay claims on 
is limited with the borders of the so-called "polar territories" of the RF (previously, "polar territories" of the USSR).

According to delimitation of the Arctic sea area based on the sectoral principle, Russia possesses a sector with the area of 7 million sq.km., 6.8 million sq.km. of which falls on the water area of the North Arctic Ocean and its seas, and 0.2 million sq.km falls on the islands. Russia is an Arctic nation which possesses the largest polar sector: the share of its sea area reaches $46 \%$ of the entire area of the North Arctic Ocean.

Since the 1982 UN Convention on the Law of the Sea has been passed, the legal status of the Arctic territory in the North Arctic Ocean has dramatically changed. The Convention confirmed complete sovereignty of the littoral states to inland sea waters (including the so-called "historical waters") and the territorial waters only (territorial sea) up to 12 sea miles wide, establishing the size of the exclusive economic zone of a state as 200 sea miles wide from the coast of the continent and the islands. The states' claims on the continental shelf were limited to 200 miles as well, though with proper proofs the external borders of the shelf may be extended to 350 miles or more. Beyond the exclusive economic zone and the continental shelf, the World Ocean, its bottom and resources are deemed territories with international order and the "common world heritage".

In this case, the exclusive economic zone and the continental shelf are not included into the state's territory, belonging to the territories of mixed order, open for navigation of vessels of all countries and flags, i.e. maintaining the open sea status. In the exclusive economic zone, a coast state exercises the domination right to mineral extraction and fishing, while beyond the continental shelf this right covers mineral extraction only. Therefore, it turns out that the state borders of the Arctic states are drawn on the external perimeter of the 12-miles' territorial sea waters surrounding the continental coast and the islands, while the state influence sector is limited to the external border of a 200-miles' exclusive economic zone with the mixed, not state, order.

In 1997 Russia chose to ratify the 1982 UN Convention, actually rejecting the sectoral approach to the division of the Arctic (though no official statements have been made in this regard). Moreover, the basic Arctic document establishes the priority of international law at the determination of Russia's Arctic Zone borders and does not mention its polar sector at all. As a result, Russia loses its sovereign power to a huge water area of the North Arctic Ocean in its sector, which used to fall on its territorial property order. According to the author's approximate calculations (Bezrukov, 2015), based on the conventional principle, the state order was pertained for the islands $(0.2$ million sq.km), inland sea and territorial waters (1.1 million sq.km) only, whereas the major part of the maritime area switched either to the mixed economic zone order (4.0 million sq.km) or an order indefinite at the present moment (1.7 million sq.km). Therefore, the maritime area beyond the 200 miles' economic zone (1.7 million sq.km) counts up to one tenth part of the whole territory of Russia.

In 2001 the authorized ministries of the RF applied to the UN for establishment of the external border of the continental shelf, thereby forming a so-called "general world heritage" (or a "international area") near the pole with the area of 0.4 million sq.km. within the polar sector of Russia besides the part of Russian shelf with the area of 1.3 million sq.km. By doing so, Russia voluntarily waived its sovereign power to the part of the maritime area and the deep-ocean floor within the borders of its polar territories marked by the Decree of the Central Executive Committee of the USSR of 15.04.1926. The UN commission for the shelf borderline issue has 
not approved the application yet, as well as the new application with additional arguments still remains unapproved.

In the meanwhile, it is clear that the approval of the pending application will bring some negative consequences for Russia. If it rejects a part of its continental shelf in the Arctic of its own accord, other Arctic nations will have no such intentions. It is absolutely obvious that the creation of such "international area" around the North pole and invitation of over 150 member states of the 1982 UN Convention for economic activity in the area does not correspond to any present or future interests of the Arctic nations, including Russia itself. As claimed by some reputable specialists (Voytolovskiy, 2009; Vylegzhanin, 2006; Nikolaev, Peshchurov, 2014; Chilingarov et.al., 2009) the way selected by the RF is politically wrong, economically unprofitable and legally unattractive.

This way, it is not creation of a "common world heritage" area in Arctic, but division of the North Arctic Ocean between the five Arctic nations only, i.e. between Russia, Canada, the USA, Denmark (Greenland) and Norway that benefits Russia. This approach conforms to the regulations of common international law as well as the previous $1958 \mathrm{UN}$ Convention for the continental shelf. One may agree with the existing recommendations (Voytolovskiy, 2009) on the practicability of withdrawing the application from the UN Commission for the shelf border. Russia has a right to do so as the said application has no power of an international treaty, being just some provisional working material.

It is advisable to divide the sea waters around the pole, located beyond the exclusive economic zones and undivided at the present moment, between the five Arctic nations based on the historically established sectoral principle. In the states with the longest coasts in the North Arctic Oceans, i.e. in Russia and Canada, this principle is fixed in the national legislation concerning the polar sectors. The said maritime spaces remain within the borders of the Arctic nations' polar sectors, keeping the legal order of their continental shelf, thereby excluding any opportunity of forming an "international common world heritage area" around the pole.

The opportunity of establishing a special legal order in the Arctic is based on the fundamental geographic differences of the North Arctic Ocean from all others: the presence of an old solid ice surface occupying the major part of its area; semiclosed character of the ocean's territory and its connection with the coasts of five states only; these five states' possession of exclusive historical right to their sectors due to the fundamental contribution into the research and development of the area; remoteness from the main international navigation routes (Nikolaev, Peshchurov, 2014). For this reason, the legal regulation of the North Arctic Ocean order cannot bear universal character, but should be of a regional (for the five Arctic nations only), reciprocal and national type. Therefore, the maritime spaces of the Arctic may remain in the jurisdiction of the five littoral countries regardless of the 1982 UN Convention on the Law of the Sea. The use of the sectoral principle for delimitation of the North Arctic Ocean bears a special significance for Russia in the first instance, as it possesses the longest sea coast and, therefore, the greatest polar sector with enormous deposits of hydrocarbons and other natural resources, relatively greater population and more developed Arctic areas in comparison with those of the other countries, as well as the exceptional role of the Northeast Passage for the life of Russian North.

The legal status of the Arctic sea areas is important both on the international and the domestic Russian level. For instance, evaluation of the development prospects of the Arctic Zone of the Krasnoyarsk Territory (Krai), as well as the 
issue of possibility and efficiency of developing the mineral resources deposited both on land and in the adjacent water areas of the Kara and Laptev Sea, are extremely important. However, the difference in the legal status of the maritime spaces makes a great impact on some aspects of developing their natural resources. Let us mention two of them.

Firstly, the said differences make a direct influence on the distribution of mineral resource extraction fees between the budgets of different levels, first of all, between the federal and regional (budgets of the constituent entities of the Russian Federation) ones. According to the Law of the Russian Federation "On inland sea waters, territorial sea and the adjacent zone of the Russian Federation" (Zakon RF No. 155, 1998), the fee for the use of living and non-living resources of the inland and territorial waters, shall be paid to the federal budget and the budget of the corresponding constituent entity of the Russian Federation adjacent to the said waters. In this case, the fee for the mineral resource extraction is distributed according to the general practice, i.e. as it is done on the land domain. At the same time, according to the RF Laws "On the exclusive economic zone of the Russian Federation" (Zakon RF No. 191, 1998) and "On the continental shelf of the Russian Federation" (Zakon RF No. 187, 1995), all payments for the use of natural resources shall be paid in full to the federal budget. Therefore, the budget of the constituent entity of the RF possessing the coast gets no income from the extraction of resources on its continental shelf, i.e. in the distance over 12 miles $(22.2 \mathrm{~km})$ from the coast.

Secondly, the differences in the legal status of maritime spaces make a considerable effect on the access to the resources belonging to companies, depending on their proprietary type. According to the RF Law "On the subsoil" (Zakon RF No. $199,2016)$ the only users of the subsoil of the continental shelf of Russia may be legal entities having sufficient experience of developing the shelf subsoil of over 5 years and the share (contribution) of the RF in the charter capitals of which constitutes over $50 \%$. As a result, such legal entities are only state companies, moreover, the sole right to hydrocarbon extraction in the shelf of Russian seas, including Arctic ones, belongs to Rosneft and Gazprom state corporation. However, having got control over the $80 \%$ of the Russian shelf, these companies are not always capable of increasing the development speed, but more effective private subsoil users are legally not allowed to do survey or development of the shelf. A bright example is the situation faced by a large private oil extraction and processing company of Lukoil, which had been struggling for the access to the shelf deposits for several years. Particularly, Lukoil had pretentions to the East Taymyr oil deposit located in the North of the Krasnoyarsk Territory (Krai) on the coast of Khatanga Bay of the Laptev Sea with the adjacent territorial waters and the continental shelf (Potapov, 2016). As a result, Lukoil scarcely got a licence to explore the dryland part of the area (Potapov, 2016).

\section{Conclusion}

In the $21^{\text {st }}$ century, the North and the Arctic territories of Russia have become the key objects of political and economic processes of global scale. Scientific substantiation for delimitation is a relevant, and at the same time an extremely challenging problem of Russian science. More research is still to be done about drawing the Southern border of the North, its internal division, relation of the dryland Arctic Zone with the Extreme Zone area. The tasks of delimitation of the Arctic and the North Arctic Ocean in particular, where Russia cannot afford suffering the irrecoverable loss, bring even more responsibility. Some deeper survey is also required for the issues of dividing rights 
between the federation and the constituent entity of the Russian Federation, or the Krasnoyarsk Territory (Krai), concerning the use of natural resources found in the territories and water areas with different legal orders (statuses): the continental dryland and islands (state territory administered by the Krai), inland sea waters and the territorial sea (state territory administered by the Federation), exclusive economic zone and the continental shelf (territories with mixed legal order in the limited jurisdiction of the Russian Federation).

\section{References}

Alaev, E.B. (1983) Sotsial'no-ekonomicheskaia geografia: Ponyatiyno-terminologicheskiy slovar' [Socioeconomic Geography: Term Definitions Dictionary]. Moscow: Mysl', 350 p.

Bezrukov, L.A. (2015) Politiko-geograficheskie problemy delimitatsii Severa i Arktiki Rossii [Political and Geographic Problems of delimitation of the Russian North and the Arctic], In: Geografiia i prirod. resursy [Geography and Natural Resources] (4), p. 68-80.

Chilingarov, A.N., Gruzinov, V.M., Sychev, Iu.F. (2009) Ocherki po geografii Arktiki [Arctic Geography Essays]. Obninsk: Artifeks, 248 p.

Ekonomika Sibiri v razreze shirotnykh zon [Siberian Economy in the Latitude Zone Aspect] (1985), edited by A.G. Granberg. Novosibirsk: Nauka, Siberian Branch. 256 p.

Konovalov, A.M. (2014) Prostranstvennoe razvitie Arkticheskoy zony Rossiyskoi Federatsii na osnove modernizatsii ekonomiki Rossii [Spatial Development of the Arctic Zone of the Russian Federation Based on Russian Economy Development], In: Sovremennye proizvoditel'nye sily [Modern Production Powers] (1), p. 51-64.

Nikolaev, A.N., Peshchurov, I.S. (2014) Pravovye vozmozhnosti predotvrashcheniia poteri Rossiey vysokoshirotnogo uchastka arkticheskogo shel'fa [Legal Ways of Avoiding Russia's Loss of the High Latitude Part of the Arctic Shelf], In: Sovremennye proizvoditel'nye sily [Modern Production Powers], (1), p. 65-85.

Osnovy gosudarstvennoy politiki Rossiyskoi Federatsii v Arktike na period do 2020 goda $i$ dal'neishuyu perspektivu. - Utv. Prezidentom RF 18.09.2008 g. [Basic State Policy of the Russian Federation in the Arctic for the Period until the Year 2020 and Further Prospective, Approved by the Decree of the President of the RF of September 18, 2008] (2009), In: Rossiyskaia gazeta [The Rossiyskaia Gazeta], March 312009.

Perechen' rayonov Kraynego Severa i mestnostey, priravnennykh k nim [List of the Extreme North Areas and Equated Localities] (2002), In: Uroven' zhizni naseleniia Rossiyskoy Federatsii. Pravovaia osnova minimal'nykh denezhnykh dokhodov [Life Standards of the Population of the Russian Federation. Legal Basis for Minimum Wages] (2) Moscow: All-Russian Centre for Life Standards, 120 p.

Potapov, M. (2016) «LUKoil» obustroit Arktiku [LUKoil shall Develop the Arctic], In: Ekspert [The Expert], (7), p. 72-74.

Slavin, S.V. (1961) Promyshlennoe i transportnoe osvoenie Severa SSSR [Industrial and Transportation Development of the USSR North], Moscow: Ekonomizdat, 303 p.

Ukaz Prezidenta $R F$ «O sukhoputnykh territoriyakh Arkticheskoi zony Rossiiskoi Federatsii» ot 2.05. 2014 g. № 296 [Decree of the President of the RF “On Land Territories of the Arctic Zone of the Russian Federation No. 296 of May 02, 2014], available at http://docs.cntd.ru/document/499093267 (Accessed on January 26, 2015). 
Voytolovskiy, G.K. (2009) Vzgliad na sistemnoe morepol'zovanie. Vkhozhdenie v marinistiku [Opinion of Systematic Sea Use. Introduction to Maritime Studies]. Moscow: Kraft, 528 p.

Vylegzhanin, A.N. (2006) Aktual'nye problemy mezhdunarodno-pravovogo obespecheniia morskoy deyatel'nosti [Actual Problems of International Legal Support of the Maritime Activities], In: Teoriia i praktika morskoy deiatel'nosti [Theory and Practice of Maritime Activities] (7). Moscow: SOPS, p. 83-110.

Zakon RF «Ob iskliuchitel'noy ekonomicheskoi zone Rossiyskoy Federatsii» ot 17.12.1998 g. № 191 - FZ. [Law of the Russian Federation "On the Exclusive Economic Zone of the Russian Federation" No. 191-FZ of December 17, 1998], In: Ros. Gazeta [The Rossiyskaia Gazeta], December 24, 1998.

Zakon $R F$ «O vnutrennikh morskikh vodakh, territorial'nom more $i$ prilezhashchey zone Rossiyskoy Federatsii» ot 31.07.1998 g. № 155 - FZ. [Law of the Russian Federation “On Inland Sea Waters, Territorial Sea and the Adjacent Zone of the Russian Federation" No. 155-FZ of July 31, 1998, In: Ros. Gazeta [The Rossiyskaia Gazeta], August 6, 1998.

Zakon RF «O kontinental'nom shel’ fe Rossiiskoi Federatsii» ot 30.11.1995 g. № 187 - FZ. [Law of the Russian Federation "On the Continental Shelf of the Russian Federation” No. 187-FZ of November 30, 1995, In: Ros. gazeta [The Rossiyskaia Gazeta], December 7, 1995.

Zakon RF «O nedrakh» ot 21.02.1992 g. № 2395-1 [Law of the Russian Federation “On Subsoils" No. 2395-1 of February 21, 1992] (1992), In: Ros. gazeta [The Rossiyskaia Gazeta] (199) edited on July 03, 2016.

\title{
Географические и правовые проблемы делимитации арктических территорий Красноярского края
}

\author{
Л.А. Безруков \\ Институт географии им. В.Б. Сочавы СО РАН, \\ Россия, 664033, Иркутск, ул. Улан-Баторская, 1
}

\begin{abstract}
Рассмотрены географические и правовые проблемы делимитаџии Севера и Арктики Красноярского края. Исходя из законодательного выделения Севера, дана характеристика трех основных широтных зон Красноярского края - Юга (Южного широтного пояса), Ближнего Севера, Дальнего (Крайнего) Севера - и соответствующих им приниипов территориальной политики. Указано на недостаточную обоснованность делимитации Арктической зоны на суше, особенно на имеющиеся противоречия между ее границами и границами зоны Крайнего Севера. Раскрыта проблема политико-правовой неурегулированности разграничения акватории Северного Ледовитого океана, возникшая после вступления в силу Конвенции ООН по морскому праву 1982 г., поскольку ее основные положения принципиально не совпадают с исторически сложившимся делением Арктики на пять полярных секторов, принадлежащих России, Канаде, США, Дании и Норвегии. Освещены вопросы влияния различий в правовом статусе морских пространств Арктики на особенности освоения их природных ресурсов.
\end{abstract}

Ключевые слова: Арктика, Север, делимитация, морское пространство, правовой статус. 
Статья подготовлена при финансовой поддержке РГНФ и Красноярского краевого фонда науки (проект № 16-12-24007 «Разработка долгосрочных сценариев и организационно-экономических механизмов развития Арктической зоны Красноярского края и оченка их влияния на сочиальноэкономическое состояние и динамику Красноярского края»).

Научная спещиальность: 25.00.24 - экономическая, сочиальная, политическая и рекреационная география. 